\title{
The Langsdorff's expedition to Brazil and its mammal collection kept in the Zoological Institute of St. Petersburg, Russia
}

\author{
Alexei V. Abramov \& Galina I. Baranova \\ ABSTRACT. All the available collecting data on the mammal collection made during the 1822-1829 \\ Brazil expedition under the leadership by G.I. Langsdorff are provided. The collection is kept in the \\ Zoological Institute of the Russian Academy of Sciences, St. Petersburg and at present contains 184 \\ specimens of 74 species and 26 families of the orders Didelphimorphia, Cingulata, Pilosa, Primates, \\ Lagomorpha, Chiroptera, Carnivora, Perissodactyla, Artiodactyla, and Rodentia.
}

KEY WORDS: Brazil, Langsdorff, mammals.

AlexeiV.Abramov [abramov@zin.ru] and Galina I. Baranova, Zoological Institute, Russian Academy of Sciences, Universitetskaya nab. 1, St. Petersburg 199034, Russia.

\section{Коллекция млекопитающих, собранных экспедицией Лангсдорфа в Бразилии, хранящаяся в Зоологическом институте РАН (Санкт-Петербург)}

\begin{abstract}
А.В. Абрамов, Г.И. Баранова
РЕЗЮМЕ. Приведена информация о млекопитающих, собранных в 1822-1829 гг. экспедицией Г.И. Лангсдорфа в Бразилии. В настоящее время в Зоологическом институте РАН (Санкт-Петербург) хранятся 184 экземпляра (74 видов, 26 семейств) из бразильских сборов Г.И. Лангсдорфа. В коллекции представлены виды, относящиеся к отрядам Didelphimorphia, Cingulata, Pilosa, Primates, Lagomorpha, Chiroptera, Carnivora, Perissodactyla, Artiodactyla и Rodentia.
\end{abstract}

КЛЮЧЕВЫЕ СЛОВА: Бразилия, Лангсдорф, млекопитающие.

\section{Introduction}

The famous naturalist Baron de Langsdorff, Georg Heinrich von Langsdorff (1774-1852), was born in Germany. But he lived and worked in Russia for a long time and was better known by his Russian name, Grigorii Ivanovitch Langsdorff. He was a member of and correspondent for the Russian Imperial Academy of Sciences. As a naturalist and physician, Langsdorff took part in the famous Russian scientific round-theworld expedition in 1803-1805 under the leadership of I.F. Kruzenshtern. Later, he explored Kamchatka and the Aleutian Islands. Yet, his most celebrated achievement seemed to be the expedition to Brazilian inland areas.

In 1812, Langsdorff was nominated the consul general of Russian Empire in Rio de Janeiro, Brazil. He acquired a fazenda Mandioca to the north of Rio de Janeiro where he spent time collecting plants, animals, and minerals. Mandioca became a sort of scientific centre for the study of Brazilian flora, fauna, and geography by many Russian and foreign travelers, naturalists and scientists who happened to visit this place during the second decade of the XIX century. Amongst them were Faddey Bellingshausen, Vasily Golovnin,
Johann Baptist von Spix, Carl Friedrich Philipp von Martius, Augustin Saint-Hilaire, and others.

In 1821, Langsdorff suggested the Russian Academy of Sciences to organize a large scientific expedition to unexplored Brazilian inland areas. With approval by the Russian Tsar Alexander-the-First, he received a financial and administrative support for this grandiose project (see Bertels et al., 1973), which consisted of several trips to various parts of Brazil (see Fig. 1) and covered the period from 1822 to 1829 .

Besides Langsdorff, the expedition team included the zoologist Édouard Ménétries, the botanist Ludwig Riedel, the astronomer and cartographer Nestor Rubtsov, and three painters, Johann Moritz Rugendas, Adrien Taunay, and Hércules Florence. The splendid paintings of Rugendas, Taunay, and Florence were just recently published (Expedição..., 1988). During 1822 the hunter and taxidermist Georg Freireis also took part in the expedition. Rugendas left the expedition at the end of 1824. In 1825, the physician and naturalist Christian Hasse replaced Ménétries who returned back to Russia.

In the autumn of 1822, naturalists undertook a short three-month trip to the mountainous area of Serra dos Órgãos near Rio de Janeiro. In 1823, Langsdorff and his companions travelled throughout Rio de Janeiro Province, collecting near Mandioca, Sumidouro, 


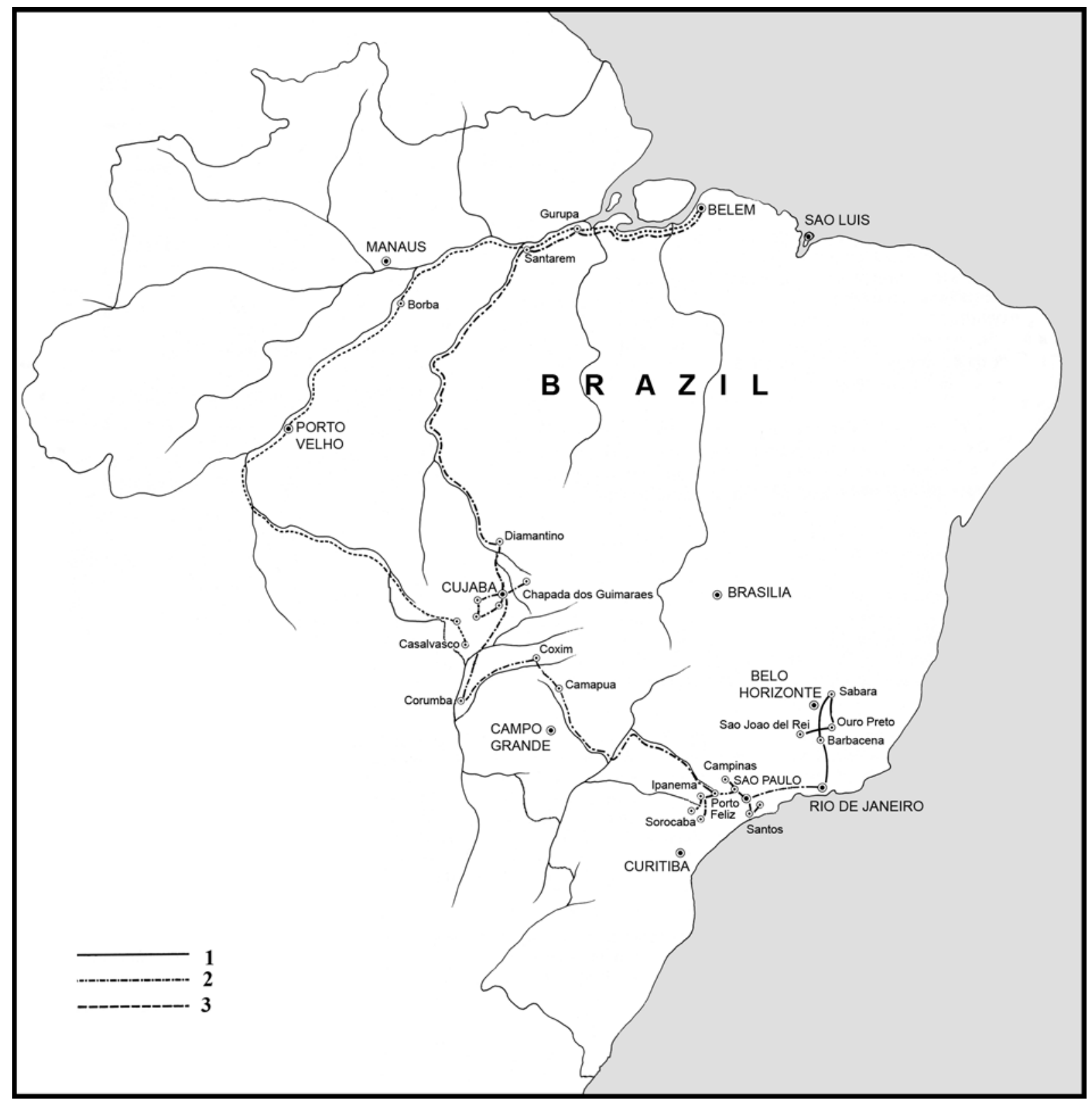

Figure 1. Map of the routes of the Langsdorff's expedition (1822-1829) in Brazil. 1 - itinerary to the Minas Gerais Province, 2 - itinerary across the São Paulo up to the northern Brazil, 3 - itinerary to the northern Brazil covered by Riedel (see text for details).

Sumambaia, and also visited River Paraíba (Paraíba do $\mathrm{Sul})$.

The next trip started from Mandioca in May 1824. Naturalists travelled over different parts of Minas Gerais Province, working around Barbacena and investigating Rio das Mortes and Rio das Pombas. In August 1824, the expedition moved to Ouro Preto, then went to Serra da Lapa and the vicinities of Tijuco. In February 1825, the expedition came back to Mandioca after covering over $1000 \mathrm{~km}$.

The largest of Langsdorff's trips started in August 1825. Langsdorff, Rubtsov, Taunay, and Florence trav- elled by sea from Rio to the village of Santos. The second group consisted of Riedel and Hasse and travelled to São Paulo by land. For a few months the expedition worked in São Paulo Province. In June 1826, after extensive preparations, the fluvial phase of Langsdorff expedition to the Amazon started, with 40 people and 7 boats departing from Porto Feliz by the River Tietê. In seven months, in January 1827, and having travelled over $4000 \mathrm{~km}$, naturalists had reached Cuiabá in Mato Grosso Province, where they would then have worked until November 1827. The expedition was then divided into two groups. The first party which consisted 
of Langsdorff, Rubtsov, and Florence crossed Pantanal in the Matto Grosso following the rivers Arinos, Juruena, and Tapajós. This group was able to reach Santarém on the River Amazon in July 1828. The second party of Riedel and Taunay had the task of following the rivers Guaporé and Madeira in order to reach Manaus on the River Amazon. Both parties eventually met, but with enormous difficulties and sufferings during their trips. Adrien Taunay drowned in the River Guaporé. Most of the participants became ill with tropical fevers (most probably, the yellow fever), including Langsdorff himself. As a consequence of the febrile attacks, the Baron became insane at the River Juruena in May 1828. The parties joined in Belém do Pará and returned to Rio de Janeiro on shipboard on 13th March 1829, almost three years after the start of the expedition and having covered a distance of over $6000 \mathrm{~km}$. Thereafter, in 1830, Langsdorff returned to Europe and died in Freiburg, Germany, in 1852. His serious illness prevented him from doing any research, and this was an irreparable loss for the science.

Enormous scientific collections made by Baron de Langsdorff and his companions were brought to St. Petersburg during 1822-1830 and originally preserved in the Kunstkamera. Later on, they formed the basis of South American collections of several Russian scientific museums. The zoological collections, including mammals, were moved to the Zoological Museum (recently - Institute) of the Russian Academy of Sciences founded in 1832 .

\section{A checklist of the collected mammals}

The checklist given below is based on specimens' labels, inventory books and records in the catalogue of the Laboratory of Theriology, Zoological Institute of the Russian Academy of Sciences. Only a few original labels and field collection numbers, i.e. those that came with the specimens, have survived. Most of the specimens possess simple labels such as "Brasilia, Langsdorff" (Fig. 2). In order to clarify the collecting data we have examined the published expeditionary diaries (Diaries..., 1995) and the information from the Scientific Archive of the Russian Academy of Sciences in St. Petersburg, but no relevant references for Langsdorff's mammal specimens were available. Traditionally, large mammal specimens (representatives of the carnivores, ungulates, proboscideans, whales, and others) in the collection of the Zoological Institute Russian Academy of Sciences are provided with two different catalogue numbers: one for the skulls/skeletons (with the prefix ' $\mathrm{O}$ ' to the collection number) and another for the skins/ stuffed specimens (prefix ' $C$ '). Small mammals (rodents, lagomorphs, insectivores, bats) have the ' $\mathrm{C}$ 'kind of catalogue numbers only. Most of the specimens are kept in the collection of Laboratory of Theriology, but some of the stuffed specimens are on display in the Zoological Museum (the department of the Zoological Institute).

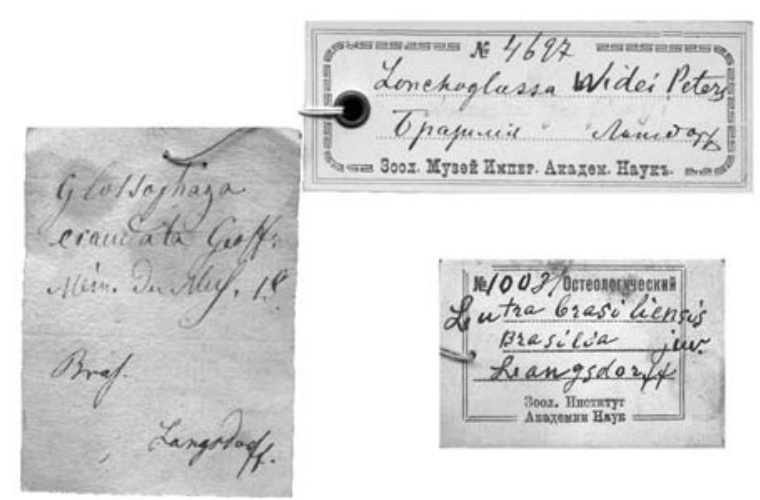

Figure 2. Some collection labels of the Langsdorff's specimens.

We have revised the taxonomy of all the collected specimens; the taxonomic order of species and common English names follows Wilson \& Reader (2005).

$$
\begin{gathered}
\text { Order Didelphimorphia } \\
\text { Family Didelphidae }
\end{gathered}
$$

Didelphis marsupialis Linnaeus, 1758 - common opossum (4 specimens).

C.1002, stuffed specimen with skull inside, female.

C.1004, stuffed specimen with skull inside, male ad.

C.1005, stuffed specimen with skull inside in Museum exposition.

O.425, def. skull, sad.

Metachirus nudicaudatus (É. Geoffroy, 1803) brown four-eyed opossum (1 specimen).

C.1007, stuffed specimen with skull inside, ad.

Micoureus cf. paraguayanus (Tate, 1931) Tate's woolly mouse opossum (1 specimen).

C.1013, stuffed specimen with skull inside in Museum exposition, male ad.

Monodelphis domestica (Wagner, 1842) - gray short-tailed opossum (1 specimen).

C.1016, stuffed specimen with skull inside in Museum exposition, ad.

Philander opossum (Linnaeus, 1758) - gray foureyed opossum (4 specimens).

C.1010, stuffed specimen.

C.1011, stuffed specimen with skull inside in Museum exposition, male.

C.1012, stuffed specimen with skull inside, sad.

O.423, def. skull. 
Order Cingulata

Family Dasypodidae

Cabassous tatouay (Desmarest, 1804) - greater naked-tailed armadillo (1 specimen).

C.324, stuffed specimen, male ad.

Cabassous unicinctus (Linnaeus, 1758) - southern naked-tailed armadillo ( 2 specimens). ad.

C.322, stuffed specimen in Museum exposition, male

C.1105, stuffed specimen, female ad.

Chaetophractus villosus (Desmarest, 1804) - big hairy armadillo (1 specimen).

C.323, stuffed specimen with skull inside in Museum exposition, female ad.

Dasypus novemcinctus (Linnaeus, 1758) - ninebanded armadillo (5 specimens).

C.320, stuffed specimen in Museum exposition, sad.

C.321, stuffed specimen, juv.

C.1107, stuffed specimen in Museum exposition, male ad.

C.1109, stuffed specimen, juv.

C.1110, stuffed specimen, male ad.

Euphractus sexcinctus (Linnaeus, 1758) - sixbanded armadillo (2 specimens).

C.1106, stuffed specimen, female ad.

C.1130, stuffed specimen, O.375, skull, male ad.

$$
\begin{gathered}
\text { Order Pilosa } \\
\text { Family Bradypodidae }
\end{gathered}
$$

Bradypus torquatus Illiger, 1811 - maned sloth (1 specimen).

C.314, stuffed specimen in Museum exposition. This is the only specimen of this species in the collection of the Zoological Institute. This rare species listed as Endangered in the IUCN Red List.

Bradypus tridactylus (Linnaeus, 1758) - palethroated sloth (1 specimen).

C.315, stuffed specimen, male ad, coll. É. Ménétries.

Family Cyclopedidae

Cyclopes didactylus (Linnaeus, 1758) - silky anteater ( 1 specimen).

C.340, stuffed specimen in Museum exposition, male ad.

\section{Family Myrmecophagidae}

Myrmecophaga tridactyla Linnaeus, 1758 - giant anteater (2 specimens).

C.339, stuffed specimen, O.373, skull, in Museum exposition.

C.1507, stuffed specimen, O.374, skull.
Tamandua tetradactyla (Linnaeus, 1758) — southern tamandua (4 specimens).

C.342, stuffed specimen, O.385, def. skull, male sad.

C.1503, stuffed specimen, sad.

C.1504, def. stuffed specimen, ad.

O.389, skull.

Order Primates

Family Aotidae

Aotus trivirgatus (Humboldt, 1811) - threestriped night monkey ( 2 specimens).

C.742, stuffed specimen with skull inside in Museum exposition, female.

C.1548, stuffed specimen in Museum exposition, O.799, skull, male ad.

\section{Family Atelidae}

Alouatta caraya (Humboldt, 1812) — black howler ( 5 specimens).

C.1502, stuffed specimen, O.34, skull, female.

C.1541, stuffed specimen in Museum exposition, O.793, skull, ad.

C.2956, skin, O.1852, skull, male sad.

C.2962, skin, O.1851, skull, female.

C.96576, skin, O.1892, skull.

Alouatta guariba (Humboldt, 1812) - brown howler (3 specimens).

C. 2947 , skin.

O.35, skull.

O.37, skull.

Alouatta seniculus (Linnaeus, 1766) - Venezuelan red howler ( 3 specimens).

C.810, stuffed specimen with skull inside, male ad.

C.1566, stuffed specimen in Museum exposition, O.794, skull, male ad.

C.2963, skin, O.1739, skull, male.

Alouatta sp. (1 specimen).

O.36, skull.

Brachyteles arachnoides (É. Geoffroy, 1806) southern muriqui (2 specimens).

C.1567, stuffed specimen, O.795, skull, male.

O.38, skull.

Lagothrix lagotricha (Humboldt, 1812) — brown woolly monkey (1 specimen).

O.42, skull, male.

\section{Family Cebidae}

Callithrix aurita (É. Geoffroy, 1812) - buffytufted marmoset (1 specimen).

C.727, stuffed specimen with skull inside. 
Callithrix jacchus (Linnaeus, 1758) - common marmoset (1 specimen)

C.2978, def. stuffed specimen, O.1857, skull.

Callithrix melanura (É. Geoffroy, 1812) - blacktailed marmoset (3 specimens).

C.1374, def. stuffed specimen, O.57, skull ad.

C.1516, stuffed specimen, O.803, skull without mandibles, female ad.

C.1517, stuffed specimen, O.802, skull, ad.

Cebus apella (Linnaeus, 1758) - tufted capuchin (7 specimens).

C.761, stuffed specimen with skull inside.

C.764, stuffed specimen with skull inside in Museum exposition, male ad.

C.768, stuffed specimen with skull inside in Museum exposition, female.

C.1098, stuffed specimen with skull inside.

C.2953, skin, O.1930, skull, male.

C.2957, skin, O.2211, skull, female.

C.2960, skin, O.1911, skull.

Cebus capucinus (Linnaeus, 1758) - white-headed capuchin ( 1 specimen).

C.747, stuffed specimen with skull inside.

Leontopithecus rosalia (Linnaeus, 1766) - golden lion tamarin ( 1 specimen).

C.2967, skin, O.1913, skull, female.

Family Pitheceiidae

Callicebus personatus (É. Geoffroy, 1812) - Atlantic titi (6 specimens).

C.739, stuffed specimen in Museum exposition, O.45, skull, female ad.

C.1376, stuffed specimen in Museum exposition, O.47, skull, male ad.

C.2959, def. skin, O.1750, skull, female.

C.2970, def. skin, O.1938, def. skull, female.

C. 2979 , def. skin.

O.2051, skull.

Order Lagomorpha

Family Leporidae

Sylvilagus brasiliensis (Linnaeus, 1758) - tapeti

(3 specimens).

C.286, def. stuffed specimen, skull.

C.287, stuffed specimen, juv.

C.12562, def. skin, skull without mandibles.

Order Chiroptera

Family Emballonuridae

Saccopteryx bilineata (Temminck, 1838) - greater sac-winged bat (1 specimen).

C.88672, def. skin and def. skull.
Family Phyllostomidae

Anoura geoffroyi Gray, 1838 - Geoffroy's tailless bat ( 3 specimens).

C.4697, skin, def. skull.

C.88600, skin, def. skull.

C.88601, skin, def. skull.

Artibeus lituratus (Olfers, 1818) - great fruiteating bat ( 2 specimens).

C.4696, skin, skull.

C.88626, skin, skull.

Artibeus sp. (1 specimen).

C.88625, skin, skull.

Carollia perspicillata (Linnaeus, 1758) - Seba's short-tailed bat ( 7 specimens).

C.4693, skin, skull.

C.4718, skin, skull.

C.4734, skin, skull.

C.88547, skin, def. skull.

C.88548, skin, def. skull.

C.88549, skin, def. skull.

C.88550, skin, def. skull.

Chiroderma sp. (1 specimen).

C. 1729, def. skull, coll. E. Ménétries.

The specimen identified by Dr. Karl F. Koopman (pers. comm., 1974).

Glossophaga soricina (Pallas, 1766) - Pallas's long-tongued bat (2 specimens).

C.4705, skin, skull.

C.88546, skin, skull.

Phyllostomus hastatus (Pallas, 1767) - greater spear-nosed bat ( 5 specimens).

C.1731, def. stuffed specimen, def. skull. male.

C.1732, skin, def skull.

C.1733, stuffed specimen in Museum exposition, skull, female.

C.88631, skin, skull.

C.88651, def. skull.

Platyrrhinus lineatus (E. Geoffroy, 1810) — whitelined broad-nosed bat (1 specimen).

C.88630, skin, def. skull.

Pygoderma bilabiatum (Wagner, 1843) - Ipanema broad-nosed bat (1 specimen).

C.1730, def. skull.

The specimen identified by Dr. Karl F. Koopman (pers. comm., 1974).

Sturnira lilium (E. Geoffroy, 1810) - little yellow-shouldered bat ( 4 specimens).

C.4688, skin, def. skull.

C.88543, skin, def. skull. 
C.88544, skin, def. skull.

C.88545, skin, def. skull, Minas Geraes, coll. É. Ménétries.

Family Noctilionidae

Noctilio leporinus (Linnaeus, 1758) - greater bulldog bat ( 2 specimens).

C.4689, skin, def. skull.

C.4700, skin, def. skull.

\section{Family Vespertilionidae}

Histiotus velatus (I. Geoffroy, 1824) - tropical big-eared brown bat ( 4 specimens).

C.4694, skin, def. skull.

C.88676, def. skin, def. skull.

C.88677, def. skin, def. skull.

C.88678, skin, def. skull.

Lasiurus cf. ega (Gervais, 1856) - southern yellow bat (1 specimen).

C.4687, skin, skull.

According to opinion of Dr. Leila Maria Pessôa (pers. comm., 2004) this specimen can be Lasiurus borealis.

Myotis cf. nigricans (Schinz, 1821) - black myotis ( 7 specimens).

C.4695, def. skin, parts of skull.

C.4721, skin with def. skull inside.

C.88753, def. skin with skull inside.

C.88754, skin with def. skull inside.

C.88755, skin, def. skull.

C.88756, def. skin with def. skull inside.

C.88757, def. skin with def. skull inside.

These specimens were identified by Dr. Alex Borissenko (pers. comm., 1995).

\section{Order Carnivora \\ Family Felidae}

Panthera onca (Linnaeus, 1758) - jaguar (4 specimens).

C.1404, skin, ad.

C.1678, stuffed specimen in Museum exposition, male ad.

O.5738, skull, ad.

O.5740, skull, sad

Puma concolor (Linnaeus, 1771) - cougar (2 specimens).

C.1290, skin, ad.

C.1680, stuffed specimen in Museum exposition, male ad.

Puma yagouaroundi (É. Geoffroy Saint-Hilaire, 1803) - jaguarundi (1 specimen).

C.1288, stuffed specimen in Museum exposition, O.1362, skull, ad.
Leopardus geoffroyi (d'Orbigny et Gervais, 1844)

- Geoffroy's cat (1 specimen).

C.3024, skin, O.1393, skull, male ad.

Leopardus pardalis (Linnaeus, 1758) — ocelot (1 specimen).

C.3017, skin, O.8212, skull, ad.

Family Canidae

Chrysocyon brachyurus (Illiger, 1815) - maned wolf (1 specimen).

C.1271, stuffed specimen in Museum exposition, O.970, skull, female ad.

Cerdocyon thous (Linnaeus, 1766) - crab-eating fox ( 3 specimens).

C.644, stuffed specimen in Museum exposition, ad.

C.645, def. stuffed specimen, ad.

C.647, stuffed specimen with skull inside, juv.

Family Mustelidae

Eira barbara (Linnaeus, 1758) - tayra (2 specimens).

C.959, stuffed specimen, O.17567, def. skull, ad.

C.93284, stuffed specimen, O.2667, skull, sad.

Lontra longicaudis (Olfers, 1818) - Neotropical otter (1 specimen).

O.3230, skin, O.10035, skull, sad.

Pteronura brasiliensis (Gmelin, 1788) - giant otter (1 specimen).

C.3240, skin, O.10031, skull, juv.

Family Procyonidae

Nasua nasua (Linnaeus, 1766) - South American coati ( 9 specimens).

C.929, stuffed specimen, O.17536, skull.

C.931, stuffed specimen, O.17625, skull, ad.

C.932, stuffed specimen, O.17535, skull, ad.

C.1312, stuffed specimen with skull inside.

C.3213, stuffed specimen with skull inside.

C.3215, stuffed specimen.

C.3220, stuffed specimen with skull inside.

O.751, skull, ad, coll. É. Ménétries.

O.755, skull, sad, coll. É. Ménétries.

Procyon cancrivorus G. Cuvier, 1798 - crabeating raccoon ( 1 specimen).

C.3219, skin, O.759, skull, ad.

Order Perissodactyla

Family Tapiridae

Tapirus terrestris (Linnaeus, 1758) - South American tapir (4 specimens).

O.7205, skull, ad.

O.7206, skull, ad. 


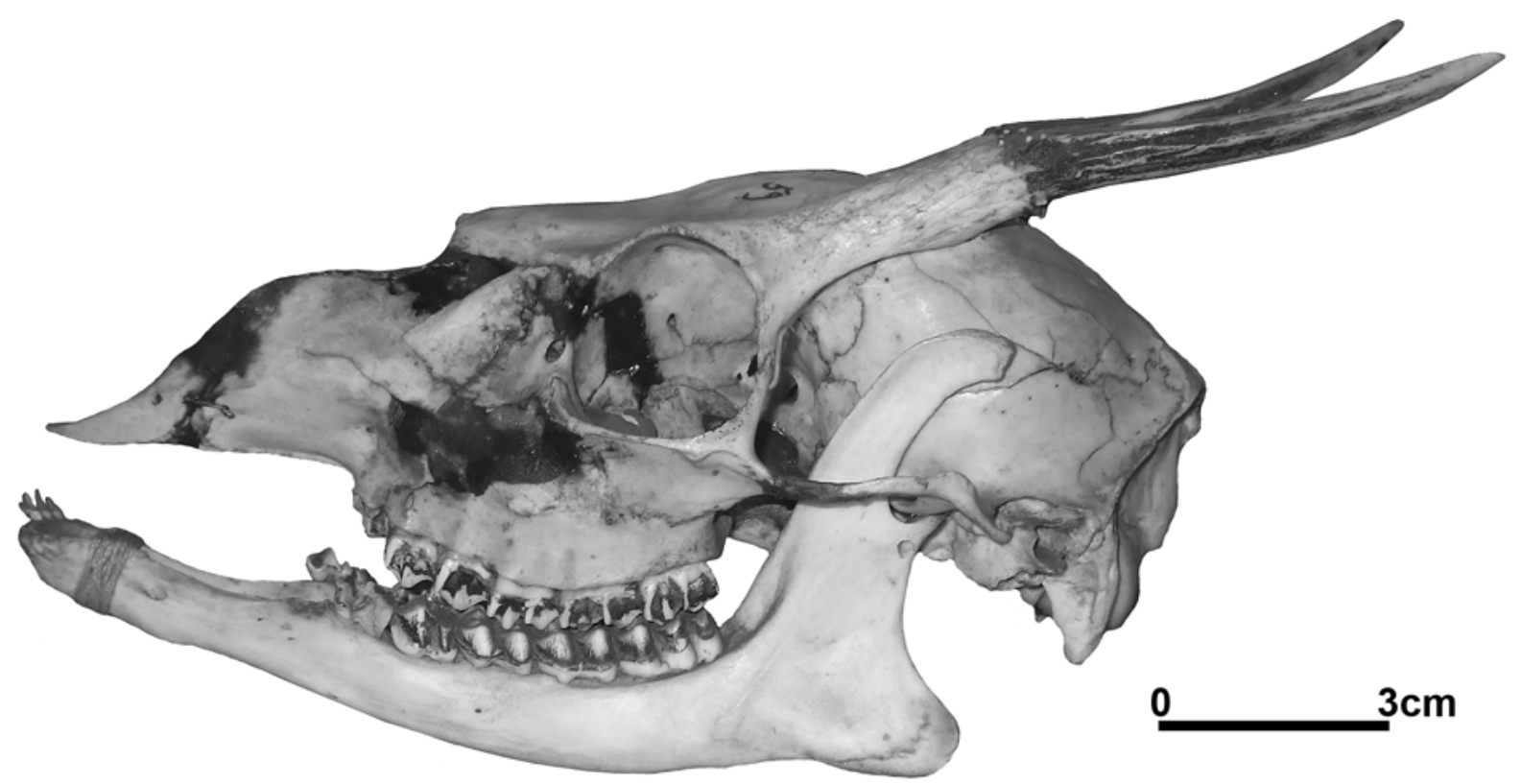

Figure 3. Skull of Mazama cf. gouazoubira (O.2359). Scale bar is $3 \mathrm{~cm}$.

O.7207, skull, ad.

O.7209, skull, ad.

Order Artiodactyla

Family Tayassuidae

Pecari tajacu (Linnaeus, 1758) - collared peccary (2 specimens).

C.97336, skin, O.1579, skull, female ad.

O.1339, skull, female ad.

Tayassu pecari (Link, 1795) - white-lipped peccary (1 specimen).

O.1558, skull.

\section{Family Cervidae}

Blastocerus dichotomus (Illiger, 1815) - marsh deer (6 specimens).

C.4640, skin, O.6441, def. skull, male juv.

C.4660, skin, O.11350, skull, male ad.

O.1258, skull, male ad.

O.1259, skull, male ad.

O.1260, skull, male ad.

O.1261, skull, female ad.

Mazama cf. gouazoubira (G. Fischer von Waldheim, 1814) - South American brown brocket (1 specimen).

O.2359, skull, male ad (Fig. 3).

Order Rodentia

Family Sciuridae

Sciurus (Urosciurus) spadiceus Olfers, 1818 southern Amazon red squirrel (3 specimens).
C.412, skin, skull, male. This is the paralectotype (Baranova \& Gromov, 2003: 8) of Sciurus langsdorffii Brandt, 1835.

C.415, stuffed specimen with skull inside, male. This is the lectotype (Baranova \& Gromov, 2003: 8) of Sciurus langsdorffii Brandt, 1835 (Fig. 4).

C.69337, def. skull. This is the paralectotype (Baranova \& Gromov, 2003: 8) of Sciurus langsdorffii Brandt, 1835.

\section{Family Erethizontidae}

Coendou prehensilis (Linnaeus, 1758) - Brazilian porcupine ( 3 specimens).

C.34, stuffed specimen with skull inside in Museum exposition.

O.6593, def. skull. This is the holotype of Hystrix brandtii Jentink, 1879.

O.6594, def. skull.

Sphiggurus spinosus (F. Cuvier, 1823) - Paraguaian hairy dwarf porcupine ( 3 specimens).

C.30, stuffed specimen with skull inside in Museum exposition. This is the holotype of Cercolabes (Sphiggurus) nigricans Brandt, 1835.

C.31, stuffed specimen ad. This is the holotype of Cercolabes (Sphiggurus) affinis Brandt, 1835.

C.33, stuffed specimen, juv.

Sphiggurus villosus (F. Cuvier, 1823) - orangespined hairy dwarf porcupine ( 3 specimens).

C.32, skin.

O.338, skull (tooth-rows incomplete).

O.401, def. skull. 


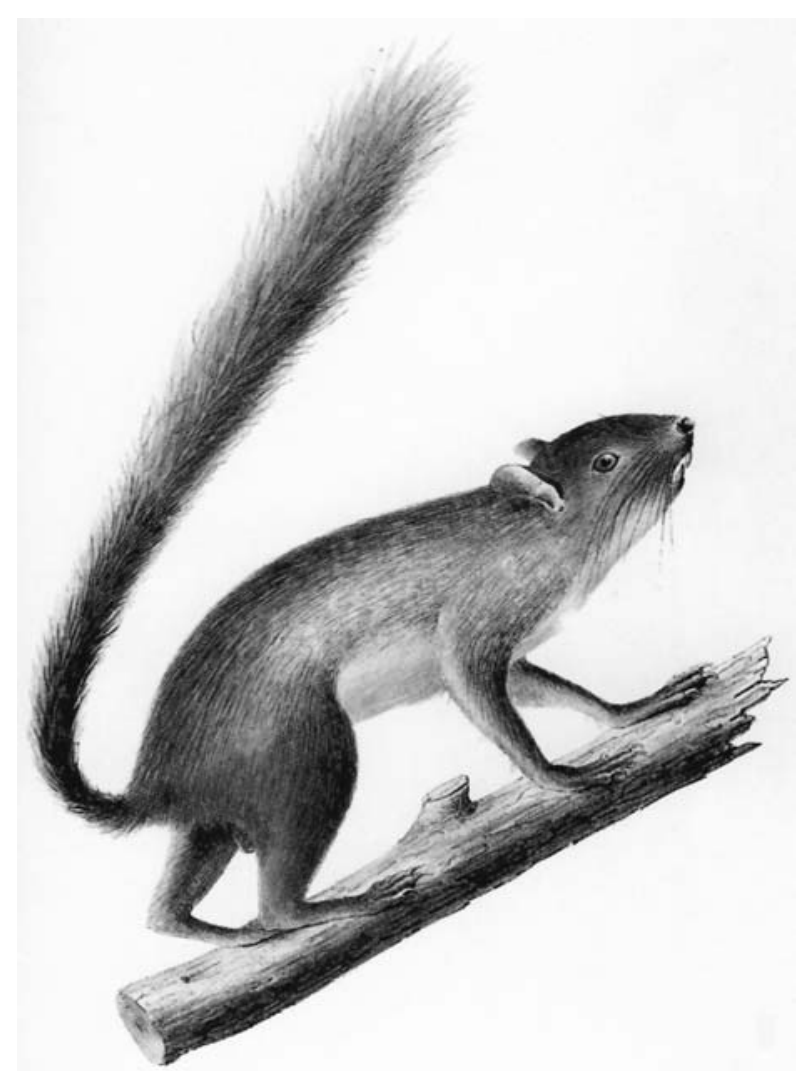

Figure 4. The picture of Sciurus langsdorffii from the original description by Brandt (1835).
Family Caviidae

Cavia aperea Erxleben, 1777 - Brazilian Guinea pig ( 2 specimens).

C.56, stuffed specimen with def. skull inside. This is the paralectotype (Baranova \& Gromov, 2003: 24) of Cavia leucopyga Brandt, 1835.

C.57, skin, def. skull. This is the lectotype (Baranova \& Gromov, 2003: 23) of Cavia leucopyga Brandt, 1835.

Galea flavidens (Brandt, 1835) - Brazilian yellow-toothed cavy (1 specimen).

N.54, stuffed specimen, def. skull inside. This is the holotype of Cavia flavidens Brandt, 1835.

Galea spixii (Wagler, 1831) - Spix's yellowtoothed cavy (1 specimen).

C.55, stuffed specimen with skull inside in Museum exposition.

Hydrochoerus hydrochaeris (Linnaeus, 1766) capybara (3 specimens).

C.303, stuffed specimen with skull inside in Museum exposition.

C.89026, skin

C.89027, skull, female ad.

Family Dasyproctidae

Dasyprocta leporina (Linnaeus, 1758) - redrumped agouti ( 8 specimens).

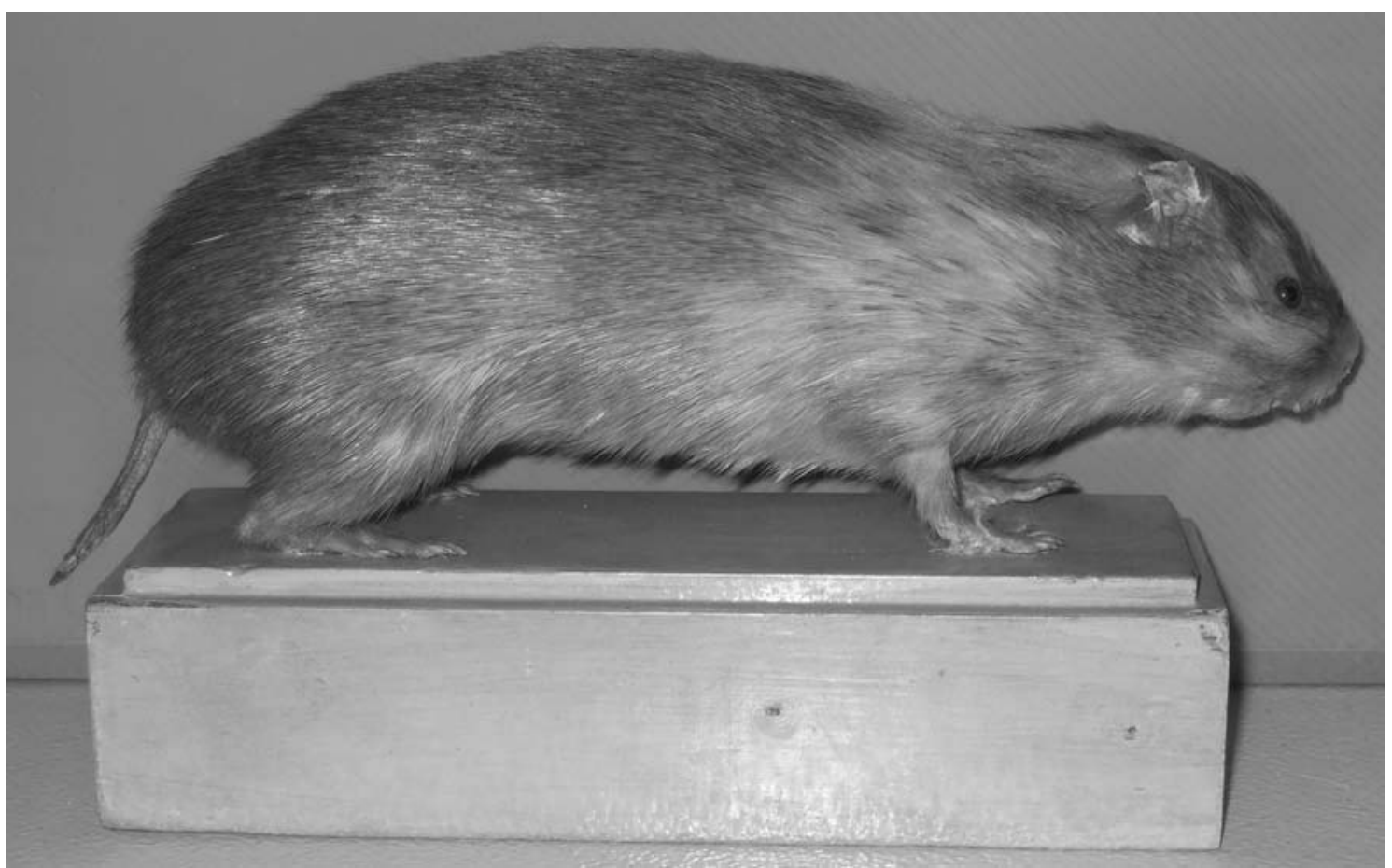

Figure 5. Stuffed specimen of Euryzygomatomys spinosus (C.234). 
All specimens of the agouti labelled as 'Dasyprocta aguti' or 'Dasyprocta acouchi'. According to the most recent viewpoint (Woods \& Kilpatrick, 2005), both belong to D. leporina.

C.63, stuffed specimen in Museum exposition.

C.86019, skin with limb bones inside, skull.

C.89020, skin with limb bones inside, skull.

C.89021, skin with skull and limb bones inside.

C.89022, skin with skull and limb bones inside.

C.89023, skull.

C.89024, skull, left zygomatic arch broken.

C.89025, skull, coll. L. Riedel.

Family Echimyidae

Euryzygomatomys spinosus (G. Fischer, 1814) guiara (1 specimen).

C.234, stuffed specimen in Museum exposition (Fig. 5), def. skull, ad, "ex oppido Ypanema, Provinciae St.Pauli, Brasiliae, January 1826, Langsdorff'. This is the holotype of Hypudaeus guiara Brandt, 1835. This is the only specimen of this species in the collection of the Zoological Institute.

Proechimys ex. gr. longicaudatus (Rengger, 1830) - long-tailed spiny-rat (1 specimen).

C.218, stuffed specimen, skull without mandibles (Fig. 6). This is the holotype of Holochilus langsdorffii Brandt, 1855. Brandt established the subgenus (genus) Holochilus for hystricomorphous neotropical spiny rats (family Echimyidae), but for over 150 years this name has been used for myomorphous neotropical marsh rats (family Sigmodontidae) (Voss \& Abramson, 1999). Under the plenary power of the ICZN (Opinion 1984, 2001) all previous fixations of type species for the nominal genus Holochilus Brandt, 1835 were set aside

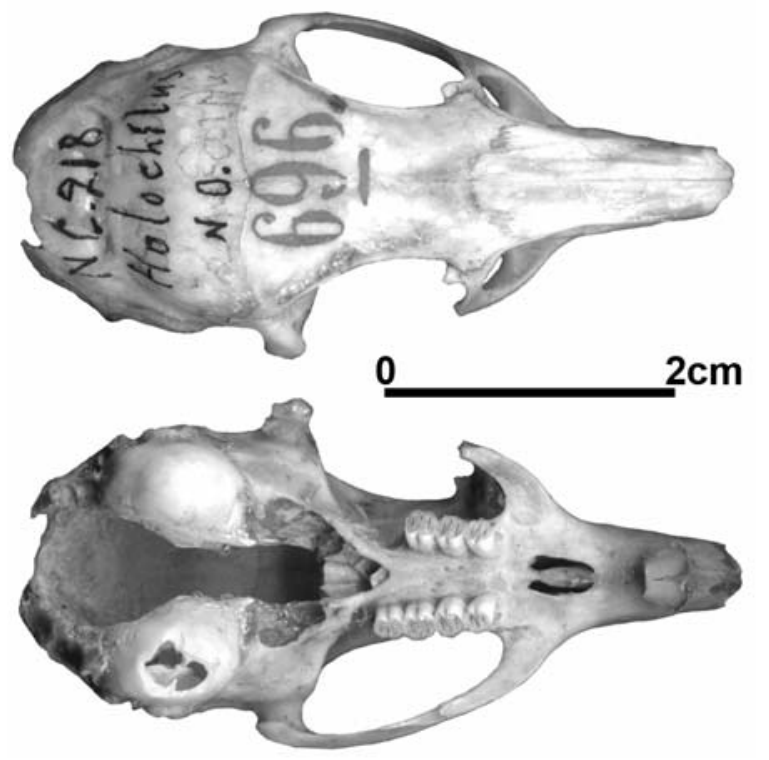

Figure 6. Skull of Proechimys ex. gr. longicaudatus (C.218). Scale bar is $2 \mathrm{~cm}$. and Holochilus sciureus Wagner, 1842 was designated as the type species in order to continue traditional usage of the genus name for a myomorphous sigmodontine. In fact, the type specimens of Holochilus leucogaster and Holochilus langsdorffii are both terrestrial spiny rats referable to the echimyid genera Trinomys and Proechimys (see Voss \& Abramson, 1999: 258).

The specific status of this specimen was clarified by Dr. Leila Maria Pessôa (pers. comm., 2004).

Trinomys iheringi (Thomas, 1911) - Ihering's Atlantic spiny-rat (1 specimen).

C.219, stuffed specimen, def. skull. This is the holotype of Mus (Holochilus) leucogaster Brandt, 1835. "Mus leucogaster" was described by Langsdorff in his unpublished manuscript "Description du rat à ventre blanc Mus leucogaster" sent to the Russian Imperial Academy of Sciences (Saint Petersburg) in 1824.

The specific status of this specimen has been clarified by Dr. Leila Maria Pessôa (Pers. comm., 2004).

\section{Conclusions}

In total 184 mammal specimens of the Langsdorff's expedition are preserved in the collection of the Zoological Institute of the Russian Academy of Sciences. There are 74 species of 26 families of the orders Didelphimorphia, Cingulata, Pilosa, Primates, Lagomorpha, Chiroptera, Carnivora, Perissodactyla, Artiodactyla, and Rodentia. These materials constitute the main part of the South American mammal collection of the Zoological Institute.

Except for the mammal collection, there is a large collection of South American marine and fresh water fishes also retained in the Zoological Institute (Neelov, 1974). Sadly, some of the ichthyological specimens collected by Langsdorff were lost during the catastrophic St. Petersburg flood in 1924 and during the Leningrad Blockade in the Second World War. Langsdorff's bird collection constituted the first South American ornithological material to be in possession of Russian museums, of which some 1000 specimens are now kept in the Zoological Institute Russian Academy of Sciences; many species are represented by large series of specimens (Potapov, 1974). There are also Langsdorff's ornithological materials (near 1000 bird specimens) in the Zoological Museum of Moscow State University (Dr. Mikhail V. Kalyakin, pers. comm., 2008).

Due to many travel hardships, the Langsdorff team was unable to collect many biological specimens. Yet, Langsdorff and his companions gathered a unique geographic and ethnographic account on indigenous people of Brazil, of those many tribes already became extinct (Komissarov, 1975, 1977). The botanical collection made by the Langsdorff expedition is held in the Botanical Institute of the Russian Academy of Sciences (St. Petersburg) is richer and consists of more than 100000 specimens. It is still one of the biggest collections of Brazilian plants in the world (Komissarov, 
1975).

Unfortunately, rich scientific records of the expedition, comprising many descriptions and discoveries in zoology, botany, mineralogy, medicine, linguistics, and ethnology, have not been properly studied yet and remain mainly unpublished. Langsdorff lost his memory after getting the yellow fever during the last trip and he was unable to study his collection by himself. Langsdorff's South American mammal collections were partly studied by the Academician F. Brandt, who described some new taxa (Brandt, 1835, 1855).

ACKNOWLEDGMENTS. We thank Dr. Leila Maria Pessôa (Universidade Federal do Rio de Janeiro, Brazil), who help us in identification of some bat and rodent specimens. Some of bat specimens were identified by Dr. Karl F. Koopman (American Museum of Natural History, USA) and Dr. Alex Borissenko (University of Guelph, Canada). We are obliged to Dr. Dmitry V. Logunov (University of Manchester, UK) for improving the English of the final draft.

\section{References}

Baranova G.I. \& Gromov I.M. 2003. [Catalogue of Type Specimens in the Collections of the Zoological Institute. Mammalia. No.4, Rodentia]. Sankt-Peterburg: Zoologicheskii Institut Rossiiskoi Akademii Nauk. 100 p. [in Russian].

Bertels D.E., Komissarov B.N. \& Lysenko T.I. (compilers). 1973. [Materials of the Langsdorff expedition to Brazil. Scientific description] // Trudy Arkhiva AN SSSR. T.25. P.1-228 [in Russian].

Brandt J.F. 1835. Mammalium rodentium exoticorum novorum vel minus rite cognitorum musei Academici zoollogici descriptiones et icones // Mémoires de l'Académie Impériale des Sciences de Saint-Pétersbourg. Série VI. Sciences mathématiques, physiques et naturelles. T. 3, Seconde partie: Sciences naturelles. T.1. Livr.4. P.357442.

Brandt J.F. 1855. Beiträge zur nähern Kentniss der Säugethiere Russland's. 5. Abhandlung: Untresuchungen über die craniologischen Entwicklungsstufen und die davon herzuleitenden Verwandtschaften und Classificationen der Nager der Jetztwelt mit besonderer Beziehung auf die Gattung Castor // Mémoires de l'Académie Impériale des Sciences de Saint-Pétersbourg. Série VI. Sciences mathématiques, physiques et naturelles. T. 9, Seconde partie: Sciences naturelles. T.7. Zoologie et Physiologie. P.125-336.

[Diaries of Russian complex academic expedition into Brazil in 1824-1826 under leadership of Academician G.I. Langsdorff]. 1995. Moskva: Nauka. 280 p. [in Russian].

Expedição Langsdorff ao Brasil. 1988. Vol.1. Rugendas, desenhos e aquarelas. $156 \mathrm{p}$. Vol.2. Taunay, desenhos e aquarelas. 160 p. Vol.3. Florence, desenhos e aquarelas. 136 p. Rio de Janeiro: Edições Alumbramento/Livroarte Editora.

Komissarov B.N. 1975. [Grigorii Ivanovitch Langsdorff. 1774-1852]. Leningrad: Nauka. 124 p. [in Russian].

Komissarov B.N. 1977. [The first Russian expedition to Brazil]. Leningrad: Nauka. 136 p. [in Russian].

Neelov A.V. 1974. [Ichthyological collections of Academician G.I. Langsdorff] // Abstracts of papers, Conference devoted to 200 years anniversary of Academician G.I. Langsdorff, Leningrad. P.25-27 [in Russian].

Potapov R.L. 1974. [Ornithological materials of Academician G.I. Langsdorff in the collection of Zoological Institute USSR Academy of Sciences] // Abstracts of papers, Conference devoted to 200 years anniversary of Academician G.I. Langsdorff, Leningrad. P.33-34 [in Russian].

Voss R.S. \& Abramson N.I. 1999. Holochilus Brandt, 1835, Proechimys J. A. Allen, 1899 and Trinomys Thomas, 1821 (Mammalia, Rodentia): proposed conservation by the designation of $H$. sciureus Wagner, 1842 as the type species of Holochilus // Bulletin of Zoological Nomenclature. Vol.56. Pt.4. Case 3121. P.255-261.

Wilson D.E. \& Reeder D.M. (eds.). 2005. Mammals Species of the World. A Taxonomic and Geographic Reference. Third edition. Baltimore: Johns Hopkins University Press. 2142 p.

Woods C.A. \& Kilpatrick C.W. 2005. Infraorder Hystricognathi // Wilson D.E. \& Reeder D.M. (eds.). Mammals Species of the World. A Taxonomic and Geographic Reference. Third edition. Vol.2. Baltimore: Johns Hopkins University Press. P.1538-1600. 